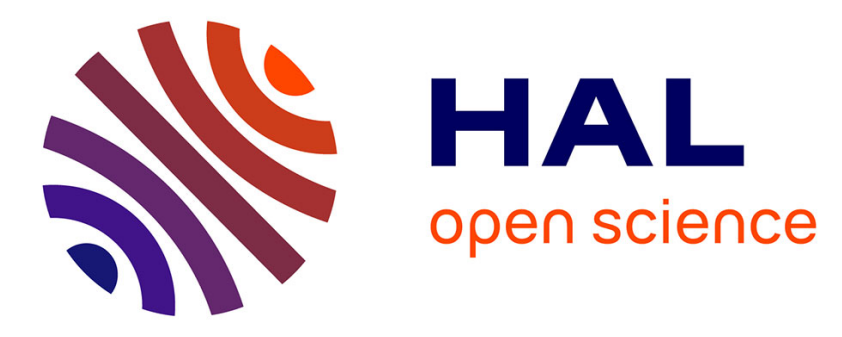

\title{
Synthesis of upconversion TiO2:Er3+-Yb3+ nanoparticles and deposition of thin films by spin coating technique
}

Fatma Trabelsi, Frédéric Mercier, Elisabeth Blanquet, Alexandre Crisci, Rached Salhi

\section{To cite this version:}

Fatma Trabelsi, Frédéric Mercier, Elisabeth Blanquet, Alexandre Crisci, Rached Salhi. Synthesis of upconversion TiO2:Er3+-Yb3+ nanoparticles and deposition of thin films by spin coating technique. Ceramics International, 2020, 46 (18), pp.28183-28192. 10.1016/j.ceramint.2020.07.317 . hal03000684

\section{HAL Id: hal-03000684 \\ https://hal.science/hal-03000684}

Submitted on 13 Nov 2020

HAL is a multi-disciplinary open access archive for the deposit and dissemination of scientific research documents, whether they are published or not. The documents may come from teaching and research institutions in France or abroad, or from public or private research centers.
L'archive ouverte pluridisciplinaire HAL, est destinée au dépôt et à la diffusion de documents scientifiques de niveau recherche, publiés ou non, émanant des établissements d'enseignement et de recherche français ou étrangers, des laboratoires publics ou privés. 
Manuscrit envoyé à Ceramics International

Publication : 2020, 46 (18), pp.28183-28192

\title{
Synthesis of upconversion $\mathrm{TiO}_{2}: \mathrm{Er}^{3+}-\mathrm{Yb}^{3+}$ nanoparticles and deposition of thin films by spin coating technique
}

\author{
Authors \\ Fatma Trabelsi ${ }^{\mathrm{a}, \mathrm{b}}$, Frédéric Mercier ${ }^{\mathrm{b}}$, Elisabeth Blanquet ${ }^{\mathrm{b}}$, Alexandre Crisci ${ }^{\mathrm{b}}$, \\ Rached Salhi ${ }^{\text {a }}$
}

\section{Affiliations}

a Laboratory of Advanced Materials, National School of Engineers of Sfax, University of Sfax, 3038 Sfax, Tunisia

b Univ. Grenoble Alpes, CNRS, Grenoble INP, SIMaP, 38000 Grenoble, France

* Corresponding authors e-mail address: fatma.trabelsi@grenoble-inp.fr

* Telephone number: +3373292327 


\begin{abstract}
In this work, a simple, low temperature $\left(\mathrm{T}<300^{\circ} \mathrm{C}\right)$ procedure suitable to increase the efficiency of solar cell and optoelectronic devices through reducing the mismatch with solar spectrum in the infrared range is proposed. $\mathrm{TiO}_{2}$ co-doped with rare earth ions is a promising candidate for its use in optical field due to the possibility to expand the spectral absorption range. Here, pure and $\mathrm{Er}^{3+}-\mathrm{Yb}^{3+}$ co-doped anatase- $\mathrm{TiO}_{2}$ nano-spherical particles (diameter < $50 \mathrm{~nm})$ with high surface area $\left(125.7 \mathrm{~m}^{2} / \mathrm{g}\right.$ and $140.6 \mathrm{~m}^{2} / \mathrm{g}$ for the pure and co-doped, respectively), good crystallinity are prepared by hydrothermal-assisted sol-gel method, followed by their dispersion and deposition as thin films. The nanoparticles are characterized by studying their structural, morphology, surface chemical compositions and photoluminescent properties. From the dispersion study, results showed that the optimal conditions were obtained for co-doped $\mathrm{TiO}_{2}$ at operational $\mathrm{pH}=3$ and with 20 min as a suitable duration of ultrasonication. The co-doped $\mathrm{TiO}_{2}$ nanoparticles showed excellent upconversion properties (green and red emissions) at room temperature under $980 \mathrm{~nm}$ excitation. To extend this result towards optoelectronic and photonic applications, the upconversion nanoparticles are deposited at the surface of n-type (100) Si wafer using a spincoating process. From scanning electron microscopy, it is observed that the entire surface of substrate is covered with a uniform film composed of compact arrangement of small nanoparticles with a good adhesion on $\mathrm{Si}$ surface, also the resulting $750 \mathrm{~nm}$ thick $\mathrm{TiO}_{2}: \mathrm{Er}-\mathrm{Yb}$ film maintained the upconversion luminescence phenomena.
\end{abstract}

\title{
Keywords
}

Sol-gel; dispersion; spin coating; Erbium; Ytterbium; upconversion 


\section{Introduction}

Application of upconversion luminescent nanoparticles composed of lanthanide ions doped inorganic host material as spectrum modifier have attracted great interest due to their outstanding luminescent properties, which are potentially used in laser materials, medical [1] and photovoltaic [2] applications. In recent years, semiconductor metal oxides $\left(\mathrm{TiO}_{2}, \mathrm{SnO}_{2}\right.$, $\mathrm{ZnO}, \mathrm{In}_{2} \mathrm{O}_{3}$ ) have been widely used as host materials due to their high thermal and chemical stability, and suitability in many applications such as photocatalysis [3], sensor devices [4], and optical devices [5]. The most commonly used material is $\mathrm{TiO}_{2}$ (titanium dioxide), due to its considerable low cost, non-toxicity, photo-stability, biological and chemical inertness [6]. Additionally, in its anatase form, $\mathrm{TiO}_{2}$ has higher electron mobility and lower dielectric constant than the rutile phase [7]. Recently, the combination of nanoscale and photoluminescent properties has attracted a lot of interest in order to achieve excellent product performances. Special attention is given to the upconversion luminescence process, in which the sequential absorption of two or more photons leads to the emission of light at shorter wavelength than the excitation wavelength. It has been proved that nanoparticles of $\mathrm{TiO}_{2}$ codoped with rare earth ions into the is a promising candidate for the usage in optoelectronics by extending the spectral range from the near-UV to the infrared region [8-17]. These ions have been extensively studied due to their specific $4 \mathrm{f}$ electronic structure and unique properties. Many rare earth couples like : $\left(\mathrm{La}^{3+}-\mathrm{Ce}^{3+}\right)$ [11], $\left(\mathrm{Sm}^{3+}-\mathrm{Eu}^{3+}\right)[9]$ and $\left(\mathrm{Y}^{3+}-\mathrm{Eu}^{3+}\right)$ [12] were inserted into $\mathrm{TiO}_{2}$. Among other rare earth ions, $\mathrm{Er}^{3+}$ and $\mathrm{Yb}^{3+}$ are recognized as an ideal couple for improving light trapping ability, because the $\mathrm{Yb}^{3+}$ acts well as a sensitizer for $\mathrm{Er}^{3+}$ activated optical materials [13-16]. The upconversion emission of $\mathrm{Er}^{3+}-\mathrm{Yb}^{3+}$ in other different host lattices for film preparation are investigated extensively $[18,19]$.

Previous reports proved that $5 \% \mathrm{Er}^{3+}-5 \% \mathrm{Yb}^{3+}$ co-doped $\mathrm{TiO}_{2}$ in powder form possesses an important quantum yield of $2.8 \pm 0.1 \%$ at a low power density of $16.7 \mathrm{~W} / \mathrm{cm}^{2}$ compared to other candidates $\left(2 \% \mathrm{Er}^{3+}-25 \% \mathrm{Yb}^{3+} \beta-\mathrm{NaYF}_{4}: 3 \pm 0.1 \%\right.$ under $\left.20 \mathrm{~W} / \mathrm{cm}^{2}\right)$, which makes it suitable for efficient upconversion in photonic applications [17]. Moreover, $\mathrm{TiO}_{2}$ co-doped 
$\mathrm{Er}^{3+}-\mathrm{Yb}^{3+}$ is a transparent material with a high refractive index $(\mathrm{n}=2.4)$ in visible wavelength, which make it widely desired for application in solar cells field [20,21].

Although upconversion $\mathrm{TiO}_{2}$ co-doped $\mathrm{Er}^{3+}-\mathrm{Yb}^{3+}$ thin films have been already investigated by several research groups for different applications, the preparation of films with a good crystallinity, high surface area and efficient green and red luminescence at temperature below $500^{\circ} \mathrm{C}$ still remains challenging. Till know, the annealing temperature that has been used in most of the studies is above $500^{\circ} \mathrm{C}$, in order to achieve high crystallinity and consequently an efficient luminescence [16], [20-23]. But, at high annealing temperatures: size, shape, phase and luminescence properties (specially the profile of the emissions) are changed.

So, the purpose of our innovative work is to investigate a simple, low temperature $\left(<300^{\circ} \mathrm{C}\right)$ process that can enhance many devices efficiency based on upconversion phenomena and also could be used for temperature-sensitive devices. It is based on a soft chemistry route to synthetize particles with a controllable phase (anatase), size (diameter $<50 \mathrm{~nm}$ ), morphology (spherical shape), a good crystallinity and high surface area in order to increase the reactivity of the material vs photons absorption and get an efficient upconversion luminescence.

First, pure and $\left(\mathrm{Er}^{3+}-\mathrm{Yb}^{3+}\right)$ co-doped $\mathrm{TiO}_{2}$ nano-spherical particles are elaborated using solgel process under supercritical drying condition of ethanol as a simple method and low cost method [24,25]. Evaluation of doping effect on structure, morphology and chemical composition of nanoparticles is conducted. Then, optimization of the nanoparticles suspensions for $1 \mathrm{~h}$ using electrostatic stabilization ( $\mathrm{pH}$, co-doping) and physical dispersion (ultrasonication) process is monitored by measuring the zeta potential, particle size distribution and SEM observations. Finally, nanoparticles deposition on silicon substrate is conducted using spin coating process as a fast and easy method to produce homogenous thin films from solution (Fig. 1). The desired thickness of the film is chosen to maintain the optical response obtained with the powder phase and be adapted to spin coating process deposition $[26]$.

Photoluminescent properties measurements on both nanopowders and film are also investigated.

\section{Materials and methods}

\subsection{Nanoparticles preparation}


Titanium (IV) iso-propoxide ( $\mathrm{Ti}\left[\mathrm{OCH}\left(\mathrm{CH}_{3}\right)_{2}\right]_{4}, 98 \%$, Sigma-Aldrich) is used as the precursor for titanium dioxide elaboration. Erbium (III) nitrate pentahydrate $\left(\mathrm{Er}\left(\mathrm{NO}_{3}\right)_{3} .5 \mathrm{H}_{2} \mathrm{O}, 99.9 \%\right.$, Sigma-Aldrich) and ytterbium nitrate pentahydrate $\left(\mathrm{Yb}\left(\mathrm{NO}_{3}\right)_{3} .5 \mathrm{H}_{2} \mathrm{O}, 99.9 \%\right.$, Sigma-Aldrich) are used as the precursors for Erbium and Ytterbium doping, respectively. The titanium isopropoxide is dissolved in a mixture of glacial acetic acid $\left(\mathrm{CH}_{3} \mathrm{COOH}, \geq 99.5 \%\right.$, CARLOERBA) and methanol $\left(\mathrm{CH}_{3} \mathrm{OH}, 99.8 \%\right.$, Fisher chemical) [15]. Then, a specific percentage of erbium and ytterbium nitrate is added leading to $\mathrm{TiO}_{2}(5$ at. $\% \mathrm{Er}-5$ at.\% $\mathrm{Yb}$ ). In the following parts, it will be labelled as $\mathrm{TiO}_{2}$ : Er-Yb. The resultant sol is magnetically stirred for 15 min at room temperature to insure the homogeneity of the solution. The dopant precursor solution is located in an autoclave of $1 \mathrm{~L}$ capacity filled with ethanol for drying under supercritical conditions $\left(\mathrm{T}=243^{\circ} \mathrm{C}, \mathrm{P}=63 \mathrm{bar}\right)$. After 3 hours of supercritical drying, a depressurization for $1 \mathrm{~h}$ down to room temperature is carried out. After that, nitrogen is injected into the autoclave for better evacuation of the solvents. Finally, to prevent the aerogel from cracking, the autoclave is opened after $24 \mathrm{~h}$. The obtained nanoparticles are calcined in air at $300^{\circ} \mathrm{C}$ for $2 \mathrm{~h}$ to evaporate the trace of the used solvents.

\subsection{Dispersion of nanoparticles}

Nanoparticles are dispersed in absolute ethanol under different operating conditions: $\mathrm{pH}$ and ultrasonication duration. The process is carried out with $0.24 \mathrm{M}$ concentration in absolute ethanol (99.99\%, Sodipro) under magnetic stirring speed of each solution at $1000 \mathrm{rpm}$ for 24 $\mathrm{h}$, in order to improve the homogeneity and reach surface equilibrium [27]. Since $\mathrm{pH}$ influences the surface charge and nanoparticles agglomeration behavior [28], its effect is investigated by adjusting the operational $\mathrm{pH}$ values from 3 to 10 with $\mathrm{HCl} / \mathrm{NaOH}(0.1 \mathrm{M})$ addition [29]. For acidic region, $\mathrm{HCl}$ is replaced with Glacial Acetic acid, which is a weak additive with a low ion concentration. Nanoparticles dispersion is done using ultrasonic treatment (ultrasonic probe, Fisher Scientific). The following sonication conditions are used : $20 \mathrm{kHz}, 500 \mathrm{~W}$, pulses with a $40 \%$ amplitude and a continuous mode for uniform dispersion [30]. In this work, low frequency is used in order to increase the dispersion rate by increasing the amplitude of the shock wave as explained in [31]. Temperature is monitored during sonication and the water bath is changed every 5 min to maintain a low constant temperature (below $30^{\circ} \mathrm{C}$ ) during the process and to avoid vaporization [32]. The distance between the sonicator tip and beaker bottom-inner surface is maintained at $2 \mathrm{~mm}$. Finally, $1 \mathrm{~min}$ of magnetic stirring is additionally applied to insure solution homogeneity. 
For $\mathrm{pH}$ variation in ethanol, the $\mathrm{pH}$-meter $\left(\right.$ sensION ${ }^{+} \mathrm{PH} 3$ basic $\mathrm{pH}$ benchtop meter) calibration is as follows: the $\mathrm{Ag} \pm \mathrm{AgCl}$ electrode is filled with an electrolyte consisting of $0.1 \mathrm{M} \mathrm{LiCl}$ in ethanol in the outer chamber and saturated $\mathrm{LiCl}$ in the inner chamber. The calibration is performed using ordinary water-based buffers resulting in an operational $\mathrm{pH}$ scale [29]. The equilibrium state is reached after $16 \mathrm{~h}$ in pure ethanol (operational $\mathrm{pH}=7$ ). $\mathrm{pH}$ value at which there is no electrical charge on nanoparticles surface, as deduced from electrokinetic measurements is marked $\mathrm{pH}_{\mathrm{iep}}$ and operational $\mathrm{pH}_{\mathrm{iep}}$ (iep: isoelectric point) for aqueous and non-aqueous medium, respectively.

\subsection{Spin coating deposition}

The substrates are n-type (100) Si wafers (CZ, thickness 250-300 $\mu \mathrm{m}$ and a resistivity 10-30 $\Omega . c m$ from Sil'tronix ST) cut in $20 \mathrm{~mm} \times 20 \mathrm{~mm}$ pieces. Prior to spin coating deposition, the substrates are cleaned with conventional Radio Corporation of America (RCA) process : a hot alkaline solution $\left(\mathrm{H}_{2} \mathrm{O}_{2}-\mathrm{NH}_{4} \mathrm{OH}-\mathrm{H}_{2} \mathrm{O}\right.$ : organic decontamination) at $70{ }^{\circ} \mathrm{C}$ for $15 \mathrm{~min}$, rinsed with deionized water, followed by a dipping into a hot acid solution (RCA2: $\mathrm{H}_{2} \mathrm{O}_{2}-$ $\mathrm{HCl}-\mathrm{H}_{2} \mathrm{O}$ : inorganic decontamination) at $70{ }^{\circ} \mathrm{C}$ for $15 \mathrm{~min}$, and rinsed again with deionized water. Hence, the n-type substrate is chosen because it contains higher amount of $\mathrm{OH}$ terminations than the p-type substrates after RCA2 process, which may affect the final density of nanoparticles on surface [33]. After cleaning, a spin-coating deposition is carried out at $1000 \mathrm{rpm}$ for $30 \mathrm{~s}$. The final step is the evaporation of the solvent by drying the substrate on a heating plate for $1 \mathrm{~min}$ at $200^{\circ} \mathrm{C}$.

\subsection{Characterization}

X-Ray diffraction is carried out on a BRUKER D8 Advanced diffractometer (SeriesII-2009) with $\mathrm{Cu} \mathrm{K} \alpha$ radiation $(\lambda=1.5418 \AA)$. The measurements are recorded in the $10-90^{\circ} 2 \theta$ range at room temperature with a step size of $0.05^{\circ}$ using a counting time of one second per step. Scanning Electron Microscopy (SEM) images are recorded with ZEISS Gemini SEM 500 type. In addition, the Brunauer-Emmett-Teller (BET) surface area is measured by $\mathrm{N}_{2}$ adsorption /desorption at $150^{\circ} \mathrm{C}$ using Micrometrics Surface Area and porosity Analyzer type. XPS analysis is performed in a Vacuum Generator XR3E2 apparatus with a $\mathrm{Mg} \mathrm{K}_{\alpha} \mathrm{X}$-ray source at $15 \mathrm{kV}, 20 \mathrm{~mA}$ to analyze the surface chemical compositions for the pure and codoped samples. Analyses are carried out at an angle of $90^{\circ}$ between the sample surface and the hemispherical analyzer. Pressure in the chamber is lower than $10^{-8} \mathrm{~Pa}$. The analyzed average area is about $40 \mathrm{~mm}^{2}$. The Photoluminescence emission spectra are assessed in a Fluoromax 4 
P model Horiba scientific modular equipment with a $150 \mathrm{~W}$ CW Ozone-free xenon arc lamp excitation source at room temperature.

Particle size distribution are measured with a Particle size analyzer VACSO $(\lambda=657 \mathrm{~nm}$, Laser power 38\%) utilizing dynamic light scattering (DLS). The temperature is set to $25^{\circ} \mathrm{C}$. Before the measurements, suspensions are diluted to a concentration of $3.610^{-4} \mathrm{M}$ suitable for DLS measurements. Then, the particle size is further confirmed by SEM for comparison with DLS results. DLS technique provides more robust data on size distribution than SEM [34]. The interfacial properties of nanoparticles (surface charge) is measured by a zeta potential analyzer: Malvern DTS 1060 model. This charge is an indication of the magnitude of the electrostatic forces that insure the stability of nanoparticles. As reported in literature, zeta potential values greater than the absolute value of $\pm 30 \mathrm{mV}$ have high degrees of stability. Dispersions with less than the absolute value of $\pm 25 \mathrm{mV}$ are relatively stable but will agglomerate due to Van Der Waals interparticle attractions $[35,36]$.

\section{Results and discussion}

\subsection{Nanoparticles Characteristics}

Fig. 2 shows the XRD patterns of pure and $\mathrm{TiO}_{2}: \mathrm{Er}-\mathrm{Yb}$ nanoparticles. All the diffraction peaks reveal the presence of pure $\mathrm{TiO}_{2}$ in the anatase phase (System: Tetragonal, ICDD Card Number: 21-1272) for the two samples. From the XRD data, no other phase such as $\operatorname{Er}_{2} \mathrm{O}_{3}$, $\mathrm{Yb}_{2} \mathrm{O}_{3}$ is evidenced, proving the incorporation of $\mathrm{Er}^{3+}$ and $\mathrm{Yb}^{3+}$ ions into the $\mathrm{TiO}_{2}$ matrix. Therefore, we can conclude that co-doping has no impact on the structure. The mean crystallite size, D, is estimated using Debye-Sherrer equation for all the diffraction peaks. From results collected in Table 1, the mean crystallite size remains almost the same after codoping. However, there is a difference in the lattice parameters, which are slightly larger for the co-doped sample than the pure one (increase by $0.16 \%$ and $0.27 \%$ for a and c parameters, respectively), which causes an anisotropic expansion of the $\mathrm{TiO}_{2}$ unit cell volume by $0.40 \%$. This indicates a distortion in the cell when the ions enter into $\mathrm{TiO}_{2}$ structure [37]. The lattice distortion degree, $\eta$, is evaluated using Williamson-Hall method as follows [38-40]:

$$
\beta_{h k l} \cos \theta=4 \eta \sin \theta+\frac{K \chi}{D}(1)
$$

Where $\beta_{\mathrm{hkl}}$ the FWHM (radians), $\theta$ the diffraction angle, $\lambda$ the $\mathrm{X}$-ray wavelength, $\mathrm{K}$ a dimensionless factor and $\mathrm{D}$ the mean crystallite size. As given in Table 1. the lattice distortion increases from $0.07 \%$ to $0.31 \%$ after co-doping. This can be explained by the large 
difference in the ionic radius between $\mathrm{Er}^{3+}(0.89 \AA)$ and $\mathrm{Yb}^{3+}(0.86 \AA)$ compared to $\mathrm{Ti}^{4+}(0.61$ $\AA$ ) which makes the replacement more difficult and leads to the distortion of the $\mathrm{TiO}_{2}$ lattice [41-43]. These results confirm the incorporation of $\mathrm{Er}^{3+}$ and $\mathrm{Yb}^{3+}$ dopant ions in the host lattice.

SEM images of the pure $\mathrm{TiO}_{2}$ and $\mathrm{TiO}_{2}$ : Er- $\mathrm{Yb}$ are given in Fig. 3a and c. The powders consist of spherical aggregates (about $3 \mu \mathrm{m}$ in diameter) with a homogenous distribution. Each aggregate is formed with mono-dispersed particles below $50 \mathrm{~nm}$ diameter for both pure $\mathrm{TiO}_{2}$ and $\mathrm{TiO}_{2}$ :Er-Yb (Fig. $3 \mathrm{~b}$ and d). BET surface area measurements show that $\mathrm{TiO}_{2}: \mathrm{Er}-\mathrm{Yb}$ possesses the largest surface area with $140.6 \mathrm{~m}^{2} / \mathrm{g}$ compared to $125.7 \mathrm{~m}^{2} / \mathrm{g}$ for the pure nanoparticles. These spherical shape and nanometer size of the particles with consequent high surface to volume ratio have an important impact on the photoluminescence properties. These characteristics can lead to more light absorption from solar spectrum and enhancement of photonic devices performance.

XPS spectra of pure $\mathrm{TiO}_{2}$ and $\mathrm{TiO}_{2}$ :Er-Yb prepared by the sol-gel method are recorded in the range of 0-900 eV. Fig. 4a shows the survey spectrum. The surface composition of nanoparticles is evaluated using the high-resolution (HR) Ti 2p, O 1s, C 1s, Yb 4d and Er 4d XPS spectra, respectively. As shown in Fig. $4 b$, the Ti $2 p$ spectrum is characterized by a doublet composed of two symmetrical Ti $2 \mathrm{p}_{3 / 2}$ and $\mathrm{Ti} 2 \mathrm{p}_{1 / 2}$ peaks at binding energies of 458.8 $\mathrm{eV}, 464.5 \mathrm{eV}$ and $458.7 \mathrm{eV}, 464.4 \mathrm{eV}$ for pure and $\mathrm{TiO}_{2}: \mathrm{Er}-\mathrm{Yb}$ respectively, generated from spin-orbit coupling and attributed to $\mathrm{Ti}^{4+}$ in $\mathrm{TiO}_{2}$ anatase $[44,45]$. Compared to pure $\mathrm{TiO}_{2}$, the $\mathrm{Ti} 2 \mathrm{p}$ peak for the $\mathrm{TiO}_{2}$ : Er-Yb moved towards low binding energy, which is a direct measure of the lowering of valence state level of $\mathrm{Ti}^{4+}$ to $\mathrm{Ti}^{3+}$. Same observation is mentioned in other reports [46].

Fig. $4 \mathrm{e}$ and $\mathrm{f}$ presents the $\mathrm{Er} 4 \mathrm{~d}_{5 / 2}$ and $\mathrm{Yb} 4 \mathrm{~d}_{5 / 2}$ spectra. Each peak could be deconvoluted into three peaks. First peaks are attributed to the $\mathrm{Er}-\mathrm{O}$ and $\mathrm{Yb}-\mathrm{O}$ bonds located at $168.7 \mathrm{eV}$ and $184.9 \mathrm{eV}$ [47]. Second peaks are related to the Er-OH and $\mathrm{Yb}-\mathrm{OH}$ bonds located at $170.8 \mathrm{eV}$ and $186.0 \mathrm{eV}$ [16]. Additional peaks located at $167.6 \mathrm{eV}$ and $183.4 \mathrm{eV}$ could be attributed to metallic bonds more probably consisting of Er-Er and $\mathrm{Yb}-\mathrm{Yb}$, respectively. The presence of the mentioned peaks confirms the presence of $\mathrm{Er}^{3+}$ and $\mathrm{Yb}^{3+}$ ions.

Fig. 4c shows the O1s peak of the two samples, that can be deconvoluted into two peaks positioned at $530.0 \mathrm{eV}, 531.5 \mathrm{eV}$ and $529.9,531.7 \mathrm{eV}$ for pure $\mathrm{TiO}_{2}$ and $\mathrm{TiO}_{2}: \mathrm{Er}-\mathrm{Yb}$ respectively. The peaks at lower binding energy are associated to surface lattice oxygen and 
the other peaks at higher binding energy are assigned to the $\mathrm{H}-\mathrm{O}$ group from the absorbed $\mathrm{H}_{2} \mathrm{O}$ on $\mathrm{TiO}_{2}$ surface. The deconvolution of $\mathrm{C}$ 1s peak revealed three different species, the peak locating at $284.9 \mathrm{eV}$ related to $\mathrm{C}-\mathrm{C}$, the other peak at $286.6 \mathrm{eV}$ assigned to $\mathrm{C}-\mathrm{OH}$ and peak at $288.6 \mathrm{eV}$ associated $\mathrm{C}=\mathrm{O}$ (Fig. 4d). The presence of carbonaceous species in XPS spectra could be attributed to the atmospheric gas adsorption and organic residues during elaboration and calcination process $[48,49]$.

\subsection{Dispersion of pure $\mathrm{TiO}_{2}$ and $\mathrm{TiO}_{2}$ : Er-Yb suspensions}

\subsubsection{Effect of pH}

The data for the pure $\mathrm{TiO}_{2}$ and $\mathrm{TiO}_{2}$ : $\mathrm{Er}-\mathrm{Yb}$ in ethanol displays an isoelectric point approximatively the same at operational $\mathrm{pH}_{\mathrm{iep}}=3.8$ (Fig. 5a). This is located in the same range of isoelectric point of $\mathrm{TiO}_{2}$-anatase in ethanol medium in previous report [50]. It should be noted that it is lower than the range determined in aqueous media $\left(\mathrm{pH}_{\mathrm{iep}}=5.5-7\right)$ [51]. That indicates that the dispersion of nanoparticles in ethanol leads to an acidification of the medium [29].

As shown in Fig. 5a, additives with $0.1 \mathrm{M}$ cannot provide the stability of the pure and codoped suspensions since values higher than the absolute value of $\pm 25 \mathrm{mV}$ cannot be obtained. Result show a decrease of the surface charge after an acid modification even lower than $\mathrm{HCl}$ with $0.1 \mathrm{M}$, which induce non-stability of nanoparticles. To provide additional information about the behavior of the dispersed nanoparticles, the evolution of these suspensions with time in the stationary state is also investigated (Fig. 5b). The pure $\mathrm{TiO}_{2}$ and $\mathrm{TiO}_{2}: \mathrm{Er}-\mathrm{Yb}$ suspensions are settled within 1 hour for operational $\mathrm{pH}=5,7,8$ and 10 due to the low charge occurred on surface. For $\mathrm{pH} \mathrm{3}$, zeta potential is approximatively the highest value $(+14 \mathrm{mV})$ and from the evolution in time, it provides a short time stability. The $\mathrm{TiO}_{2}$ : Er- $\mathrm{Yb}$ suspension remains stable after 2 hours while the pure $\mathrm{TiO}_{2}$ starts to sediment. Same results concerning the zeta potential and sedimentation time are found in [52].

In fact, these additives increase the ionic strength too much, thus compressing the ionic cloud, called electrical diffuse double layer composed by the nanoparticle surface charge and its counter ions, that surrounding the interacting nanoparticles [53]. This layer plays a fundamental role in the electrostatic stabilization because its compression can lead to more attractive van der Waals forces that cause coagulation as observed. The stability period of 2 hours is enough to perform the spin coating step (total duration less than 1 hour). 


\subsubsection{Dispersion with ultrasonic assistance and doping effect}

Effect of ultrasonication (US) duration using probe on the average particle size is studied under various time: $0 \mathrm{~min}, 10 \mathrm{~min}, 20 \mathrm{~min}$ and $30 \mathrm{~min}$, in order to achieve the maximum dispersion. From DLS results collected in Fig. 6a and b, pure $\mathrm{TiO}_{2}$ and $\mathrm{TiO}_{2}$ : Er- $\mathrm{Yb}$ suspensions present different behavior. Pure $\mathrm{TiO}_{2}$ is unstable and aggregation takes place. Different particle size distribution is obtained after each ultrasonication time. On the contrary, for $\mathrm{TiO}_{2}$ : Er- $\mathrm{Yb}$ a uniform size distribution is formed, $10 \mathrm{~min}$ of ultrasonication is enough to break the nanoparticles apart and ensure incipient stability. The size is rapidly reduced with the increasing of ultrasonication time to $20 \mathrm{~min}$ from $580 \mathrm{~nm}$ to $166 \mathrm{~nm}$ for $\mathrm{TiO}_{2}$ : Er-Yb. This reduction is due to the intense stress produced by cavities collapsing induced in liquid by ultrasonic vibrations, that can fragment the agglomerates into smaller aggregates [54]. The differences in the decreasing rates between the present study and other studies can be attributed to the effect of the nanoparticle primary size, synthesis method and material types $[55,56]$. As it is found from DLS results, $10 \mathrm{~min}$ to $20 \mathrm{~min}$ is the duration range to obtain small particles. As the ultrasonic time exceeds $20 \mathrm{~min}$, a notable observation in Fig. $6 \mathrm{c}$, is that the polydispersity index (PDI) is increased due to the coalescence of the nanoparticles. From the ultrasonication point of view, it is reported in literature that high power of ultrasonication could re-agglomerate the particles as a result of the increased collision of particles [57,58]. The improvement of $\mathrm{TiO}_{2}: \mathrm{Er}-\mathrm{Yb}$ dispersion with ultrasonication compared to the pure $\mathrm{TiO}_{2}$ can be attributed to the influence of $\mathrm{Er}^{3+}$ and $\mathrm{Yb}^{3+}$ ions that change the electronic structure, surface charge behavior and surface reactivity, which is demonstrated through the increasing in BET surface area showed previously that generates a high surface reactivity. Also, $\mathrm{TiO}_{2}: \mathrm{Er}-$ $\mathrm{Yb}$ results in a positive charge imbalance, therefore, active acidic sites will be formed, increasing the amount of hydroxyl groups absorbed [59]. Thereby, nanoparticles are expected to be modified by the surface complexity which affects the intrinsic stability and provides agglomeration in agreement with $[59,60]$.

\subsection{Deposition of dispersed nanoparticles on Si wafers}

The deposits quality with varying the ultrasonication duration is shown in Fig. 7. The SEM micrographs are in a good agreement with DLS measurements concerning the effect of ultrasonication duration. It is observed that the highest density of deposited nanoparticles increased with increasing ultrasonication time. In addition, it shows the enhancement of the film quality (minimum number of huge particles from the top view) deposited using co-doped 
nanoparticles compared to pure nanoparticles. Our process leads to the deposition of $\mathrm{TiO}_{2}$ :Er$\mathrm{Yb}$ nanoparticles with a elementary size below $50 \mathrm{~nm}$.

The performance of this step depends on the ability of nanoparticles to adhere to substrate. The silicon substrate possesses an hydrophilic surface and it is negatively charged after the RCA procedure [61]. Since the nanoparticles are positively charged at operational $\mathrm{pH}=3$, a good adhesion between the substrate and the nanoparticles is expected [62]. Two different tests are conducted to evaluate the adhesion of $\mathrm{TiO}_{2}: \mathrm{Er}-\mathrm{Yb}$ on substrate: the first one by rinsing the substrate with water and the second by blowing it with a nitrogen gas gun. The SEM images in Fig. 8a and b, show effectively a total coverage of substrate after these two tests indicating a good adhesion between the co-doped nanoparticles and the substrate.

The XRD pattern of $\mathrm{Si} / \mathrm{TiO}_{2}: \mathrm{Er}-\mathrm{Yb}$ is provided in Fig. 8c. As the deposit is not very thick and dense, the measurement is quite noisy. Nevertheless, all the diffraction peaks reveal the presence of the anatase phase (System: Tetragonal, ICDD Card Number: 21-1272). No secondary phases are detected after spin coating deposition of $\mathrm{TiO}_{2}: \mathrm{Er}-\mathrm{Yb}$.

\subsection{Up-conversion emission of nanoparticles and thin film}

Fig. 9a shows the upconversion luminescence spectrum of pure $\mathrm{TiO}_{2}$ and $\mathrm{TiO}_{2}: \mathrm{Er}-\mathrm{Yb}$ nanoparticles at room temperature under $980 \mathrm{~nm}$ excitation. No emission is observed for pure $\mathrm{TiO}_{2}$, while $\mathrm{TiO}_{2}:$ Er-Yb exhibited three emission peaks. The upconversion emissions located at $550 \mathrm{~nm}, 525 \mathrm{~nm}$ (green region) and $655 \mathrm{~nm}$ (red region), are attributed to ${ }^{2} \mathrm{H}_{11 / 2} \rightarrow{ }^{4} \mathrm{I}_{15 / 2}$, ${ }^{4} \mathrm{~S}_{3 / 2} \rightarrow{ }^{4} \mathrm{I}_{15 / 2}$, and ${ }^{4} \mathrm{~F}_{9 / 2} \rightarrow{ }^{4} \mathrm{I}_{15 / 2}$ transitions, respectively. The upconversion mechanism is detailed as follow:

$$
\begin{aligned}
& \left(\mathrm{Yb}^{+3}\right){ }^{4} \mathrm{~F}_{7 / 2}+\mathrm{h}_{980 \mathrm{~nm}} \rightarrow{ }^{4} \mathrm{~F}_{5 / 2} \\
& \left(\mathrm{Er}^{+3}\right){ }^{4} \mathrm{I}_{15 / 2}+\mathrm{h}_{980 \mathrm{~nm}} \rightarrow{ }^{4} \mathrm{I}_{11 / 2} \\
& \left(\mathrm{Er}^{+3}\right)^{4} \mathrm{I}_{15 / 2}+\left(\mathrm{Yb}^{+3}\right){ }^{4} \mathrm{~F}_{5 / 2} \rightarrow\left(\mathrm{Er}^{+3}\right){ }^{4} \mathrm{I}_{11 / 2}+\left(\mathrm{Yb}^{+3}\right){ }^{4} \mathrm{~F}_{7 / 2} \\
& \left(\mathrm{Er}^{+3}\right){ }^{4} \mathrm{I}_{11 / 2}+\left(\mathrm{Yb}^{+3}\right){ }^{4} \mathrm{~F}_{5 / 2} \rightarrow\left(\mathrm{Er}^{+3}\right){ }^{4} \mathrm{~F}_{7 / 2}+\left(\mathrm{Yb}^{+3}\right){ }^{4} \mathrm{~F}_{7 / 2}
\end{aligned}
$$

Then, due to the short life time of the ${ }^{4} \mathrm{~F}_{7 / 2}$ level in $\mathrm{Er}^{+3}$, non-radiative decay to the lower ${ }^{2} \mathrm{H}_{11 / 2}$ and ${ }^{4} \mathrm{~S}_{3 / 2}$ levels takes place, then a relaxation of the populated levels to the ground state ${ }^{4} \mathrm{I}_{15 / 2}$, resulting in the green emission (hv ${ }_{525 \mathrm{~nm}, 550 \mathrm{~nm})}$ observed:

$\left(\mathrm{Er}^{+3}\right)^{2} \mathrm{H}_{11 / 2} \rightarrow\left(\mathrm{Er}^{+3}\right){ }^{4} \mathrm{I}_{15 / 2}+\mathrm{ho}_{525 \mathrm{~nm}}$ 
$\left(\mathrm{Er}^{+3}\right){ }^{4} \mathrm{~S}_{3 / 2} \rightarrow\left(\mathrm{Er}^{+3}\right){ }^{4} \mathrm{I}_{15 / 2}+\mathrm{hv}_{550 \mathrm{~nm}}$

Red emission (hv660nm) is generated from non-radiative relaxation from the ${ }^{4} \mathrm{~S}_{3 / 2}$ to ${ }^{4} \mathrm{~F}_{9 / 2}$ level and cross relaxation process $(\mathrm{CR})$ :

$\mathrm{CR}:\left(\mathrm{Er}^{+3}\right){ }^{4} \mathrm{~F}_{7 / 2}+\left(\mathrm{Er}^{+3}\right){ }^{4} \mathrm{I}_{11 / 2} \rightarrow\left(\mathrm{Er}^{+3}\right){ }^{4} \mathrm{~F}_{9 / 2}$

$\left(\mathrm{Er}^{+3}\right){ }^{4} \mathrm{~F}_{9 / 2} \rightarrow\left(\mathrm{Er}^{+3}\right){ }^{4} \mathrm{I}_{15 / 2}+\mathrm{hv}_{660 \mathrm{~nm}}$

The high intensity of the ${ }^{4} \mathrm{~S}_{3 / 2} \rightarrow{ }^{4} \mathrm{I}_{15 / 2}$ transition in comparison with the ${ }^{2} \mathrm{H}_{11 / 2} \rightarrow{ }^{4} \mathrm{I}_{15 / 2}$ can be explained by the fast quenching of the second transition by non-radiative relaxation. The intensity of the emission in red is lower than that in green due to a weak absorption cross relaxation $[63,64]$.

Top view and cross section of the film deposited on n-type (100) Si are shown in Fig. 9c and d. SEM reveals that the film is composed of a dense arrangement of nanoparticles through all the layer thickness $(750 \mathrm{~nm})$. Similar profiles with the same peak positions of green and red emissions are observed when comparing the powder phase and the deposited film, indicating that basic optical behaviour of the upconversion nanoparticles has not been changed and that is further confirmed by the presence of the same structure (anatase phase) and elementary size. Many factors are responsible for the changing of the red / green ratio for $\mathrm{Er}^{3+}$ doped upconversion materials, such as site symmetry, coordination number, interatomic distance, shaping material [65-68]. Meanwhile, the change in intensity could be related to the change of the environment when particles are connected to n-type (100) Si surface. In addition, the amount of particles deposited on the surface of silicon substrate that lead to layer with $750 \mathrm{~nm}$ thick with porosity not the same as a compact pellet (powder phase).

\section{Conclusions and perspectives}

A simple, low temperature $\left(\mathrm{T}<300^{\circ} \mathrm{C}\right)$ procedure suitable to increase the efficiency of solar cell and optoelectronic devices through reducing the mismatch with solar spectrum in the infrared range is proposed. Through a careful optimization of the different steps: nanoparticules synthesis, dispersion, spin coating, the microstructure, the phase and the composition of the films are controlled. The obtained films composed of $\mathrm{TiO}_{2}: \mathrm{Er}-\mathrm{Yb}$ nanoparticles with diameter $<50 \mathrm{~nm}$ exhibit good adhesion to the substrate and maintain the upconversion luminescence response of nanoparticles after dispersion and spin deposition. 
As demonstrated, the near-infrared photons (under $980 \mathrm{~nm}$ excitation) could be converted into the visible light (green and red emissions) using $5 \% \mathrm{Er}^{3+}-5 \% \mathrm{Yb}^{3+}$ codoped $\mathrm{TiO}_{2}$ - anatase, so, these converted photons can be reabsorbed simply by the device. This low temperature and simple multi-step process proposed leads to a promising material that provides an efficient observed optical response. As a perspective, in order to enhance the durability of this material, its protection with an inert thin layer to external aggressive environment conditions (degradation from humidity and oxygen) will be investigated.

\section{Acknowledgement}

The authors are grateful to Rachel Martin, Thierry Encinas and Stéphane Coindeau from C.M.T.C for their support in SEM characterizations and XRD patterns analysis, respectively. Cecile Sillard from Grenoble INP-Pagora for facilities to DLS measurements, Laure Cointeaux from Grenoble INP, LEPMI for her help for providing as the dispersion equipment and Gregory Berthomé from Grenoble INP, SIMaP-TOP for XPS measurements.

\section{References}

[1] Z. Wang, DC. Thang, Q. Han, X. Zhao, X. Xie, Z. Wang, J. Lin, B. Xing, Near-infrared photocontrolled therapeutic release via upconversion nanocomposites, J Control Release. 324 (2020) 104-123. doi:10.1016/j.jconrel.2020.05.011

[2] J. Christiansen, J.V. Petersen, S. Roesgaard, S.H. Møller, R.E. Christiansen, O. Sigmund, S.P. Madsen, P. Balling, B. Julsgaard, Strongly enhanced upconversion in trivalent erbium ions by tailored gold nanostructures: Toward high-efficient silicon-based photovoltaics, Sol. Energy Mater Sol. Cells. 208 (2019) 110406. doi:10.1016/j.solmat.2020.110406

[3] J. Xiao, Y. Xie, H. Cao, F. N, Disparate roles of doped metal ions in promoting surface oxidation of $\mathrm{TiO}_{2}$ photocatalysis, J. Photochem. Photobiol. A Chem. 315 (2016) 59-66. https://doi.org/101016/j.jphotochem.2015.09.013

[4] S. Barthwal, N.B.Singh, ZnO-CNT Nanocomposite: A Device as Electrochemical Sensor, Mater Today Proceedings. 4 (2017) 5552-5560. https://doi.org/10.1016/j.matpr.2017.06.012

[5] M. Bannur, A. Antony, K.I. Maddani, P.Poornesh, A. Rao, K.S Choudhari, Tailoring the nonlinear optical susceptibility $\chi(3)$, photoluminescence and optical band gap of nanostructured $\mathrm{SnO}_{2}$ thin films by $\mathrm{Zn}$ doping for photonic device applications, Physica $\mathrm{E}$ Low Dimens. Syst. Nanostruct. 103 (2018) 348-353. 
https://doi.org/10.1016/j.physe.2018.06.025

[6] B. Tryba, S. Jafari, M. Sillanpää, A.Nitta, B.Ohtani, A.W. Morawski, Influence of $\mathrm{TiO}_{2}$ structure on its photocatalytic activity towards acetaldehyde decomposition, Appl. Surf. Sci. 470 (2019) 376-385. https://doi.org/10.1016/j.apsusc.2018.11.137

[7] Fan. Q, Mcquillin. B, Ray. A. K, Turner. M. L, Seddon. A. B, High density non-porous anatase titania thin films for device, J. Phys. D. 33 (2000). 2683-2686. https://doi.org/10.1088/0022-3727/33/21/303

[8] Zikriya. M, Nadaf. Y. F, Bharathy. P. V, Renuka. C. G, Luminescent characterization of rare earth $\mathrm{Dy}^{3+}$ ion doped $\mathrm{TiO}_{2}$ prepared by simple chemical co-precipitation method, J. Rare Earths. 37 (2019) 24-31. https://doi.org/10.1016/j.jre.2018.05.012

[9] Zhang. B, Song. Z, Jin. J, Bi. W, Li. H, Chen. C, Song. H, Efficient rare earth co-doped $\mathrm{TiO}_{2}$ electron transport layer for high-performance perovskite solar cells, J. Colloid Interface Sci. 553 (2019) 14-21. https://doi.org/10.1016/j.jcis.2019.06.003

[10] Gayathri.V, Rameshbabu. M, S. Sasiflorence, K. Ravichandran, K. Ramachandran., Influence of La on nano titanium dioxide $\left(\mathrm{TiO}_{2}\right)$ based solar cell, Mater Today: Proceedings. 400 (2019) 2-5. https://doi.org/10.1016/j.matpr.2019.05.299

[11] Shi. H, Zhang. T, An. T, Li. B, Wang. X, Enhancement of photocatalytic activity of nano-scale $\mathrm{TiO}_{2}$ particles co-doped by rare earth elements and heteropolyacids, J. Colloid Interface Sci. 380 (2012) 121-127. https://doi.org/10.1016/j.jcis.2012.04.069

[12] Wang. R, Wang. F, N. S. A, Song. J, Y/Eu co-doped $\mathrm{TiO}_{2}$ : synthesis and photocatalytic activities under UV-light, J. Rare Earths. 33 (2015) 154-159. https://doi.org/10.1016/S1002-0721(14)60396-3

[13] Tianhao. Ji, Yang. Liu, Hui. Zhao, Haiyan. Du, Jiayue. Sun, G. G, Preparation and upconversion fluorescence of rare earth $\left(\mathrm{Er}^{3+}\right.$ or $\left.\mathrm{Yb}^{3+} / \mathrm{Er}^{3+}\right)$-doped $\mathrm{TiO}_{2}$ nanobelts, J. Solid State Chem. 183 (2010) 584-589. https://doi.org/10.1016/j.jssc.2010.01.004

[14] Yuan, L., Wenguang, W., Mingzhi, S., Yanfang, Y., \& Haiyan, Z, $\left(\mathrm{Yb}^{3+}, \mathrm{Er}^{3+}\right)$ co-doped $\mathrm{TiO}_{2} / \mathrm{Ag}_{3} \mathrm{PO}_{4}$ hybrid photocatalyst with enhanced activity for photodegradation of phenol, Appl. Surf. Sci. 463 (2018) 159-168. https://doi.org/10.1016/j.apsusc.2018.08.188

[15] Salhi. R, Deschanvres, J. L, Efficient green and red up-conversion emissions in Er/Yb co-doped $\mathrm{TiO} 2$ nanopowders prepared by hydrothermal-assisted sol-gel process, J. Lumin. 176 (2016) 250-259. https://doi.org/10.1016/j.jlumin.2016.03.011

[16] Xiaoli. W, Zhenlong. Z, Jianqiang. Q, Wenjia. S, Yuefeng. L, Huiping. G, Yanli. M, Enhanced Photovoltaic Performance of Perovskite Solar Cells Based on Er-Yb Co-doped $\mathrm{TiO}_{2}$ Nanorod Arrays, Electrochim. Acta. 245, 839-845. https://doi.org/10.1016/j.electacta.2017.06.032

[17] I. Benammar, R.Salhi, J.Deschanvres, R.Maalej, The Effect of Solvents and Rare-Earth 
Element (Er, $\mathrm{Yb})$ Doping on Suspension Stability of Sol - Gel Titania Nanoparticles, J. Lumin. 16 (2017) 718-726. https://doi.org/10.1109/TNB.2017.2771302

[18] C.E. Chryssou, C.W. Pitt, P.J. Chandler, D.E. Hole, Photoluminescence characterisation of $\mathrm{Er}^{3+} / \mathrm{Yb}^{3+}$ coimplanted alumina $\left(\mathrm{Al}_{2} \mathrm{O}_{3}\right)$ thin films and sapphire crystals, IEE Proc., Optoelectron. 145 (1998) 325-330. doi:10.1049/ip-opt:19982477

[19] AV. Chelnokov, J-M. Lourtioz, P. Boucaud, H. Bernas, J. Chaumont, T. Plowman, Deep erbium-ytterbium implantation codoping of low loss silicon oxynitride waveguides, Electron. Lett. 31 (1995) 636-638.

[20] RE. Rojas-Hernandez RE, NP. Barradas, E. Alves, LF. Santos, RM. Almeida RM, Upconversion emission of aluminosilicate and titania films doped with $\mathrm{Er}^{3+} / \mathrm{Yb}^{3+}$ by ion implantation and sol-gel solution doping, Surf. Coat. Technol. 355(2018) 162-168. doi:10.1016/j.surfcoat.2018.01.056

[21] Z. Yang, K. Zhu, Z. Song, D. Zhou, Z. Yin, J. Qiu, Preparation and upconversion emission properties of $\mathrm{TiO}_{2}: \mathrm{Yb}$, Er inverse opals, Solid State Commun. 151 (2011) 364 367. doi:10.1016/j.ssc.2010.12.021

[22] J.A.B. Pérez, M. Courel, R.C. Valderrama, I. Hernández, M. Pal, F.P. Delgado, N.R. Mathews, Structural, optical, and photoluminescence properties of erbium doped $\mathrm{TiO}_{2}$ films, Vaccum. 169 (2019) 108873. https://doi.org/10.1016/j.vacuum.2019.108873

[23] Y. Wu, S. Lin, J. Liu, Y. Ji, J. Xu, L. Xu, K. Chen, Efficient up-conversion red emission from $\mathrm{TiO}_{2}: \mathrm{Yb}$, Er nanocrystals, Opt. Express. 25 (2017) 22648. https://doi.org/10.1364/OE.25.022648

[24] L. Cano-Casanova, A.A. Pérez, M.A.L. Ródenas, M.C.R. Martínez, Effect of the preparation method (sol-gel or hydrothermal) and conditions on the $\mathrm{TiO}_{2}$ properties and activity for propene oxidation, Materials. 11 (2018) 2227. doi:10.3390/ma11112227

[25] S.H. Soytaş, O. Oğuz, Y.Z. Menceloğlu, Polymer nanocomposites with Decorated Metal Oxides, in: Polymer Composites with Functionalized Nanoparticles: Synthesis, Properties, and Applications, 2018, pp. 287-323. doi:10.1016/B978-0-12-8140642.00009-3

[26] P. Malliga, J. Pandiarajan, N. Prithivikumaran, K. Neyvasagam, Influence of Film Thickness on Structural and Optical Properties of Sol-Gel Spin Coated $\mathrm{TiO}_{2}$ Thin Film, IOSR-JAP. 6 (2014) 22-28. doi:10.9790/4861-06112228

[27] T.Moulina, R. Moreno, Colloidal stability of gadolinium-doped ceria powder in aqueous and non-aqueous media, J. Am. Ceram. Soc. 33 (2013) 297-303. https://doi.org/10.1016/j.jeurceramsoc.2012.08.027

[28] S. Manoranjan, S. Komkrit, S. Sirikalaya, C. Tawatchai, B. Pratim, Characterization of doped $\mathrm{TiO}_{2}$ nanoparticle dispersions, Chem. Eng. Sci. 66 (2011) 3482-3490. https://doi.org/10.1016/j.ces.2011.04.003 
[29] J.Widegren, L. Bergstro, The effect of acids and bases on the dispersion and stabilization of ceramic particles in ethanol, J. Eur. Ceram. Soc. 20 (2000) 659-665. https://doi.org/10.1016/S0955-2219(99)00199-5

[30] T. Behnaz, A.Abbassi, M. Saffar-avval, M.A. Najafabadi, Ultrasonic properties of suspensions of $\mathrm{TiO}_{2}$ and $\mathrm{Al}_{2} \mathrm{O}_{3}$ nanoparticles in water. Powder Technol. 217 (2012) 171176. https://doi.org/10.1016/j.powtec.2011.10.024

[31] S.Sumitomo, H. Koizumi, A.Uddin, Y. Kato, Comparison of dispersion behavior of agglomerated particles in liquid between ultrasonic irradiation and mechanical stirring, Ultrason Sonochem. 40 (2018) 822-831. https://doi.org/10.1016/j.ultsonch.2017.08.023

[32] I.M. Mahbubul, T.H. Chong, S.S. Khaleduzzaman, I.M. Shahrul, R. Saidur, B.D. Long, M.A. Amalina, Effect of Ultrasonication Duration on Colloidal Structure and Viscosity of Alumina - Water Nano fluid, Ind. Eng. Chem. Res. 53 (2014) 6677-6684. https://doi.org/10.1021/ie500705j

[33] M.S. Gorji, K.A. Razak, K.Y. Cheong, Gold nanoparticles deposited on linker-free silicon substrate and embedded in aluminum Schottky contact, J. Colloid Interface Sci. 408 (2013) 220-228. https://doi.org/10.1016/j.jcis.2013.07.026

[34] S. Bhattacharjee, Review article DLS and zeta potential - What they are and what they are not ?, J Control Release. 235 (2016) 337-351. https://doi.org/10.1016/j.jconrel.2016.06.017

[35] A. Kumar, C.K. Dixit, Methods for characterization of nanoparticles, Advances in nanomedicine for the Delivery of therapeutic Nucleic Acid, 2017, pp. 43-58. https://doi.org/10.1016/B978-0-08-100557-6.00003-1

[36] N. Mandzy, E. Grulke, T. Druffel, Breakage of $\mathrm{TiO}_{2}$ agglomerates in electrostatically stabilized aqueous dispersions, Powder Technol. 160 (2005) 121-126. https://doi.org/10.1016/j.powtec.2005.08.020

[37] Y. Zhao, Y.Li, X. Ren, F. Gao, H. Zhao, The Effect of Eu Doping on Microstructure , Morphology and Methanal-Sensing Performance of Highly Ordered $\mathrm{SnO}_{2}$ Nanorods Array, J.Nanomater. 53 (2017) 6677-6684. https://doi.org/10.3390/nano7120410

[38] V.D. Mote, Y. Purushotham, B. Dole, Williamson-Hall analysis in estimation of lattice strain in nanometer-sized ZnO particles, J. Theo. Appl. Phys. 6 (2012) 2251-2256. https://doi.org/10.1186/2251-7235-6-6

[39] Y.T. Prabhu, K.V. Rao, X-Ray Analysis by Williamson-Hall and Size-Strain Plot Methods of ZnO Nanoparticles with Fuel Variation, J. Sci.Res. 4 (2014) 21-28. https://doi.org/10.4236/wjnse.2014.41004

[40] H.A. Yurtsever, M. Çiftçio, The effect of rare earth element doping on the microstructural evolution of sol-gel titania powders, J. Alloy.Compd. 695 (2017) 13361353. https://doi.org/10.1016/j.jallcom.2016.10.275 
[41] R. Zamiri, A.F. Lemos, A. Reblo, H. Abbastabar, Effects of rare-earth ( Er , La and Yb ) doping on morphology and structure properties of $\mathrm{ZnO}$ nanostructures prepared by wet chemical method, Ceram. Int. 40 (2013) 1-7.

https://doi.org/10.1016/j.ceramint.2013.06.034

[42] S.D. Senol, Hydrothermal derived nanostructure rare earth (Er, Yb)-doped ZnO :

structural, optical and electrical properties, J. Mater. Sci. Mater. Electron. 27 (2016)

7767-7775. https://doi.org/10.1007/s10854-016-4765-1

[43] S. Horikoshi, Y. Minatodani, H. Tsutsumi, H. Uchida, Influence of lattice distortion and oxygen vacancies on the UV- driven / microwave-assisted $\mathrm{TiO}_{2}$ photocatalysis, J.

Photoch. Photobio A-Chem. 265 (2013) 20-28.

https://doi.org/10.1016/j.jphotochem.2013.05.010

[44] T. Pan, P. Liao, K. Chang, L. Chi, Structural and sensing characteristics of $\mathrm{Gd}_{2} \mathrm{Ti}_{2} \mathrm{O}_{7}$, $\mathrm{Er}_{2} \mathrm{TiO}_{5}$ and $\mathrm{Lu}_{2} \mathrm{Ti}_{2} \mathrm{O}_{7}$ sensing membrane electrolyte - insulator - semiconductor for biosensing applications, Electrochim. Acta. 89 (2013) 798-806.

https://doi.org/10.1016/j.electacta.2012.10.099

[45] J. Yang, Y. Hu, C. Jin, L. Zhuge, X. Wu, Structural and optical properties of Er-doped $\mathrm{TiO}_{2}$ thin films prepared by dual-frequency magnetron co-sputtering. Thin Solid Films, 637 (2017) 9-13. https://doi.org/10.1016/j.tsf.2017.03.012

[46] Z. Rao, X. Xie, X. Wang, A. Mahmood, S. Tong, M. Ge, J. Sun, Defect Chemistry of Er -Doped TiO and Its Photocatalytic Activity for the Degradation of Flowing Gas Phase VOCs, J. Phys. Chem. 123 (2019) 12321-12334.

https://doi.org/10.1021/acs.jpcc.9b02093

[47] F. Chen, J. Her, Y. Shao, Y.H. Matsuda, T. Pan, Structural and electrical characteristics of high- $\kappa \mathrm{Er}_{2} \mathrm{O}_{3}$ and $\mathrm{Er}_{2} \mathrm{TiO}_{5}$ gate dielectrics for a-IGZO thin-film transistors, Nanoscale Res. Lett. 18 (2013) 3-8. https://doi.org/10.1186/1556-276X-8-18

[48] J. Reszczynska, T. Grzybb, J.W. Sobczakc, W. Lisowskic, M. Gazdad, B. Ohtanie, A. Zaleskaa, Lanthanide co-doped $\mathrm{TiO}_{2}$ : the effect of metal type and amount on surface properties and photocatalytic activity. Appl. Surf. Sci. 307 (2014) 333-345. https://doi.org/10.1016/j.apsusc.2014.03.199

[49] J. Reszczy, T. Grzyb, J.W. Sobczak, W. Lisowski, M. Gazda, B. Ohtani, A. Zaleska,

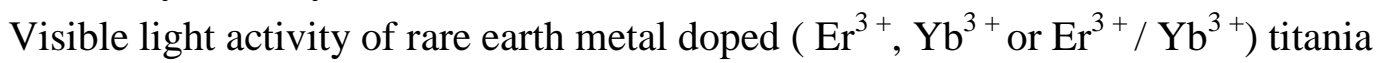
photocatalysts, App. Catal.B-Environ. 163 (2015) 40-49.

https://doi.org/10.1016/j.apcatb.2014.07.010

[50] J. Widegren, Electrostatic Stabilization of Ultrafine Titania in Ethanol, J.Am.Ceram.Soc. 28, (2002) 523-528. https://doi.org/10.1111/j.1151-2916.2002.tb00127.x

[51] G.A. Parks, A. Parks, The isoelectric points of solid oxides, solid hydrooxides and aqueous hydroxo complex systems. Chem. Rev. 65 (1964) 177-198.

https://doi.org/10.1021/cr60234a002 
[52] J. Qi, Y. Ye, H. Wang, T. Wang, F.T. Li, Dispersion and stability of titanium dioxide nanoparticles in aqueous suspension : Effects of ultrasonication and concentration, Water.Sci.Technol. 67 (2012) 147-151. https://doi.org/10.2166/wst.2012.545

[53] S.J. Park, M.K. Seo, Comprehension of nanocomposites. In Interface Science and Technology. 2011, pp. 777-819. https://doi.org/10.1016/B978-0-12-375049-5.00010-4

[54] L. Ye, X. Zhu, Y. Liu, Numerical study on dual-frequency ultrasonic enhancing cavitation effect based on bubble dynamic evolution, Ultrason. Sonochem. 59 (2019) 104-744. https://doi.org/10.1016/j.ultsonch.2019.104744

[55] K. Sato, J. Li, H. Kamiya, Ultrasonic Dispersion of $\mathrm{TiO}_{2}$ Nanoparticles in Aqueous Suspension. J.Am.Ceram.Soc. 2487 (2008) 2-8. https://doi.org/10.1111/j.15512916.2008.02493.x

[56] I.M. Mahbubul, E. Begum, R. Saidur, M.A. Amalina, Optimization of ultrasonication period for better dispersion and stability of $\mathrm{TiO}_{2}-$ water nanofluid. Ultrason. Sonochem. 37 (2017) 360-367. https://doi.org/10.1016/j.ultsonch.2017.01.024

[57] D. Uskokovic, M. Mitric, Ultrasonic de-agglomeration of barium titanate powder, Ultrason. Sonochem. 15 (2008) 16-20. https://doi.org/10.1016/j.ultsonch.2007.07.008

[58] K. Tanabe, T. Sumiyoshi, K. Shibata, T. Kiyoura, A new hypothesis regarding the surface acidity of binary metal oxides, B.Chem.Soc.Jpn. 47 (1974) 1064-1066. https://doi.org/10.1246/bcsj.47.1064

[59] K. Suttiponparnit, V. Tiwari, M. Sahu, P. Biswas, Effect of Pt or Pd doping on stability of TiO2 nanoparticle suspension in water, J.Ind.Eng.Chem. 19 (2013) 150-156. https://doi.org/10.1016/j.jiec.2012.07.017

[60] Y. Zhang, H. Zhang, Y. Xu, Y. Wang, Significant effect of lanthanide doping on the texture and properties of nanocrystalline mesoporous $\mathrm{TiO}_{2}$, J.Solid State Chem. 177 (2004) 3490-3498. https://doi.org/10.1016/j.jssc.2004.05.026

[61] J. Cloarec, C. Chevalier, J. Genest, pH driven addressing of silicon nanowires onto $\mathrm{pH}$ driven addressing of silicon nanowires onto $\mathrm{Si}_{3} \mathrm{~N}_{4} / \mathrm{SiO}_{2}$ micro-patterned surfaces, Nanotechnology. 27 (2016) 295602. https://doi.org/10.1088/0957-4484/27/29/295602

[62] N.B. Ghomrasni, C. Chivas-joly, L. Devoille, N. Feltin, Challenges in sample preparation for measuring nanoparticles size by scanning electron microscopy from suspensions, powder form and complex media, Powder Technol. 359 (2019) 226-237. https://doi.org/10.1016/j.powtec.2019.10.022

[63] R. Salhi, J.L. Deschanvres, Efficient green and red up-conversion emissions in Er/Yb co-doped $\mathrm{TiO}_{2}$ nanopowders prepared by hydrothermal-assisted sol-gel process, J. Lumin. 176 (2016) 250-259. https://doi.org/10.1016/j.jlumin.2016.03.011

[64] W. Bian, M. Zhou, G. Chen, X. Yu, M. Pokhrel, Y. Mao, Y, Upconversion luminescence of ytterbium and erbium co-doped gadolinium oxysulfate hollow nanoparticles, App. 
Mater.Today. 13 (2018) 381-386. https://doi.org/10.1016/j.apmt.2018.11.006

[65] G.T. Jassoa, E. Montesa, B. Olguína, J. Guzmána, S. Esquivela, R. I. L. Martínc, J.G. Mendozaa, Upconversion emission of $\mathrm{ZrO}_{2}$ nanoparticles doped with Erbium $\left(\mathrm{Er}^{3+}\right)$ and Ytterbium $\left(\mathrm{Yb}^{3+}\right)$, synthesized by hydrothermal route, Ceram. Int. 44 (2017) 154-157. https://doi.org/10.1016/j.ceramint.2017.09.152

[66] J. Liao, Q. Wang, L. Nie, W.You, J. Chen, Single red upconversion and near-infrared downconversion luminescence properties of cubic $\mathrm{ZrO}_{2}: \mathrm{Y}^{3+}-\mathrm{Yb}^{3+}-\mathrm{Er}^{3+}$ nanophosphors via microwave hydrothermal synthesis. Opt. Mater. 62 (2016) 479-484. https://doi.org/10.1016/j.optmat.2016.10.042

[67] L. Liang, R. Chen, Z. Mo, Color tunable up-conversion emission of $\mathrm{ZrO}_{2}: \mathrm{Yb}^{3+}, \mathrm{Er}^{3+}$ thin films prepared by chemical solution deposition, Ceram. Int. 44 (2018) 19661-19664. https://doi.org/10.1016/j.ceramint.2018.07.217

[68] D. Ramachari, D. Esparza, T. Lopez-Luke, V.H. Romero, L. Perez-Mayen, E. De la Rosa, C.K. Jayasankar, Synthesis of co-doped $\mathrm{Yb}^{3+}-\mathrm{Er}^{3+}: \mathrm{ZrO}_{2}$ upconversion nanoparticles and their applications in enhanced photovoltaic properties of quantum dot sensitized solar cells, J. Alloy. Compd. 698 (2016) 433-441. https://doi.org/10.1016/j.jallcom.2016.12.026

\section{List of Figures}

Fig. 1 The low cost procedure used in this work for the synthesis and deposition of pure $\mathrm{TiO}_{2}$ and $\mathrm{TiO}_{2}$ : Er-Yb nanoparticles.

Fig. 2 (color online) XRD patterns of pure $\mathrm{TiO}_{2}$ and $\mathrm{TiO}_{2}$ : Er-Yb nanoparticles indicating the absence the rutile phase.

Fig. 3. SEM images of $(a, b)$ pure $\mathrm{TiO}_{2}$ and $(c, d) \mathrm{TiO}_{2}$ : Er-Yb nanoparticles.

Fig. 4 (color online) XPS spectra of $\mathrm{TiO}_{2}$ (a) Survey Scan, (b) Ti2p, (c) O1s (d) C1s, (e) Er $4 \mathrm{~d}_{5 / 2}$ and (f) $\mathrm{Yb} 4 \mathrm{~d}_{5 / 2}$. Black line pure $\mathrm{TiO}_{2}$ and red line $\mathrm{TiO}_{2}: \mathrm{Er}-\mathrm{Yb}$.

Fig. 5 (color online) Zeta potential as function of operational $\mathrm{pH}$ and evolution of suspensions with time in stationary state of pure $\mathrm{TiO}_{2}$ and $\mathrm{TiO}_{2}: \mathrm{Er}-\mathrm{Yb}$.

Fig. 6 (color online) Evolution of size dispersion of (a) pure, (b) $\mathrm{TiO}_{2}:$ Er-Yb nanoparticles and (c) polydispersity index (PDI) of $\mathrm{TiO}_{2}: \mathrm{Er}-\mathrm{Yb}$ in ethanol as a function of ultrasonication time (operational $\mathrm{pH}=3$, Csolution= $0.24 \mathrm{M}, 24 \mathrm{~h}$ of magnetic stirring). 
Fig. 7 SEM images of deposited colloidal suspension of pure and $\mathrm{TiO}_{2}$ :Er-Yb under different time of ultrasonication ( $\mathrm{t}=0 \mathrm{~min}, 10 \mathrm{~min}, 20 \mathrm{~min}$ and $30 \mathrm{~min}$ ) on n-type (100) Si wafer using a spin coating process (depositing phase: $1000 \mathrm{rpm}-30 \mathrm{~s}$ and drying phase: $1 \mathrm{~min}$ at $200^{\circ} \mathrm{C}$ on a hotplate).

Fig. 8 SEM images of adhesion tests: (a) rinsed with water and (b) blown with $\mathrm{N}_{2}$ gas of $\mathrm{TiO}_{2}$ :Er-Yb film deposited on n-type (100) Si wafer using a spin coating process (depositing phase: $1000 \mathrm{rpm}-30 \mathrm{~s}$, ultrasonication time $=20 \mathrm{~min}$, cycle number: 8 and drying phase: $200^{\circ} \mathrm{C}-1$ min on a hotplate). (c) (color online) XRD pattern of n-type (100) $\mathrm{Si} / \mathrm{TiO}_{2}$ : Er- $\mathrm{Yb}$ film indicating the absence of secondary phases.

Fig. 9 (color online) Upconversion emission spectra of (a) powders of pure $\mathrm{TiO}_{2}$ and $\mathrm{TiO}_{2}: \mathrm{Er}-\mathrm{Yb}$, (b) film of $\mathrm{TiO}_{2}: \mathrm{Er}-\mathrm{Yb}$ nanoparticles deposited on n-type (100) $\mathrm{Si}$ wafer using a spin coating process under ultrasonic duration of $20 \mathrm{~min}$, (c) Top view and (d) cross section of the layer using $\lambda_{\text {excitation}}=980 \mathrm{~nm}$ as wavelength of excitation. 
Hydrothermal assisted sol-gel

nanoparticles elaboration

Step 1

Colloïdal suspension

nanoparticles dispersion: $\mathrm{pH}$ and

ultrasonication duration were studied

Step 2

Spin-coating

nanoparticles film deposition on $n$-type Si

(100) wafers

Step 3

Fig 1. 


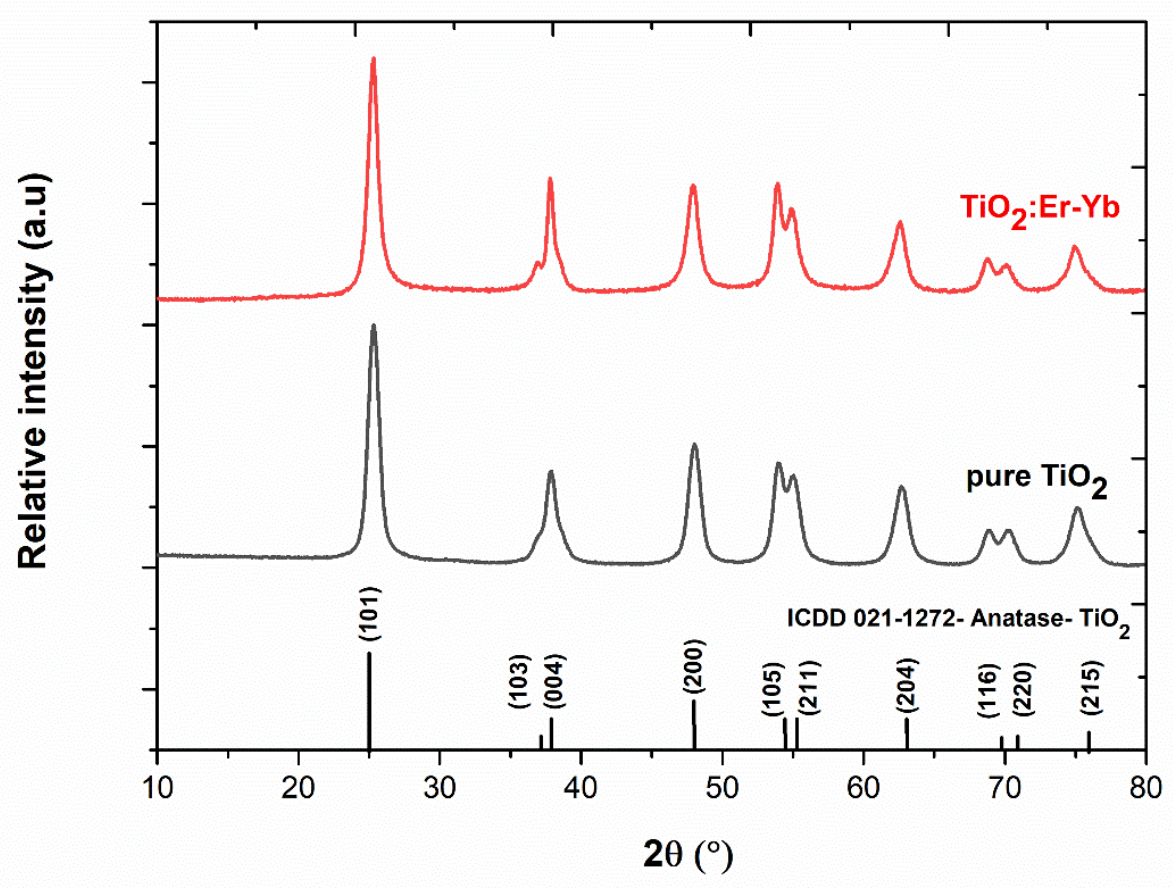

Fig 2. 

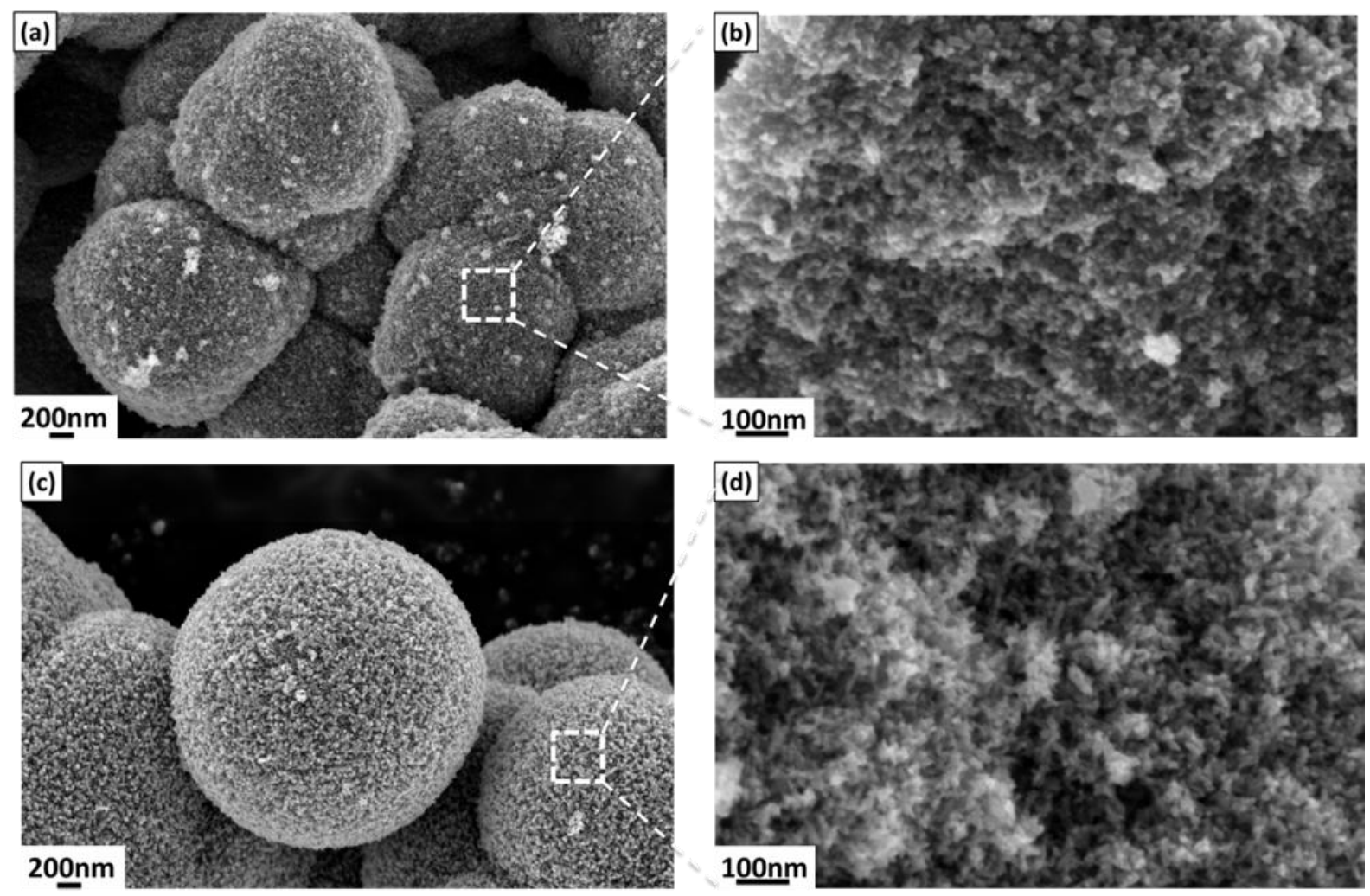

Fig 3. 

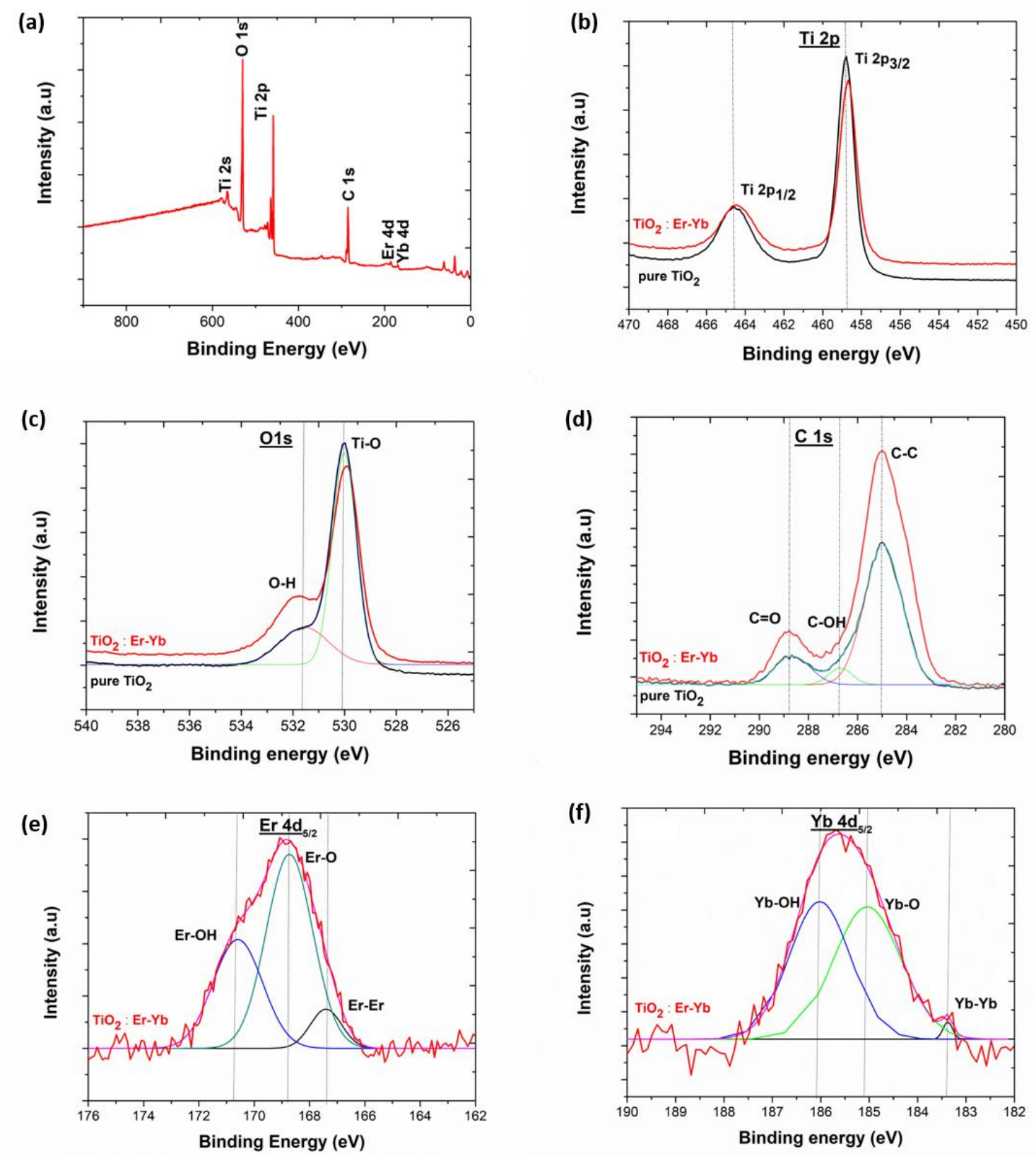

Fig 4. 


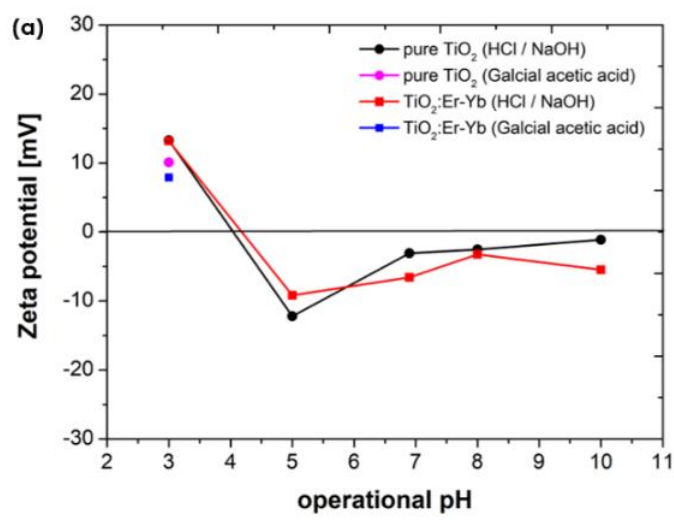

Pure $\mathrm{TiO}_{2}$ suspensions

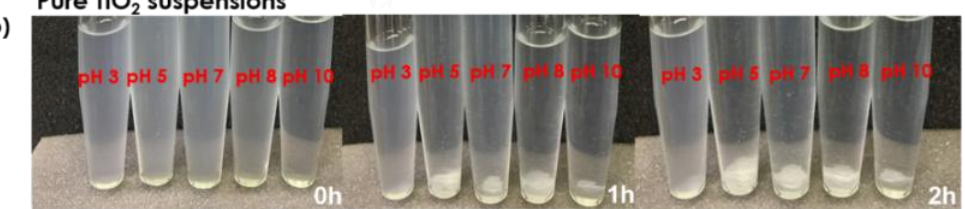

$\mathrm{TiO}_{2}: \mathrm{Er}-\mathrm{Yb}$ suspensions

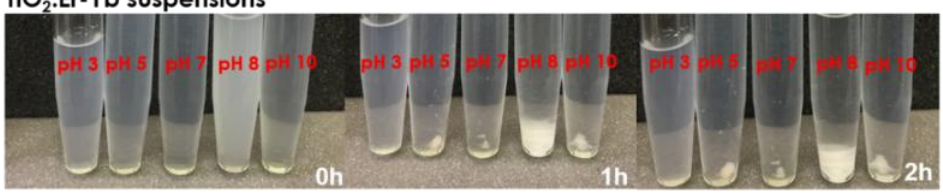

Fig 5. 

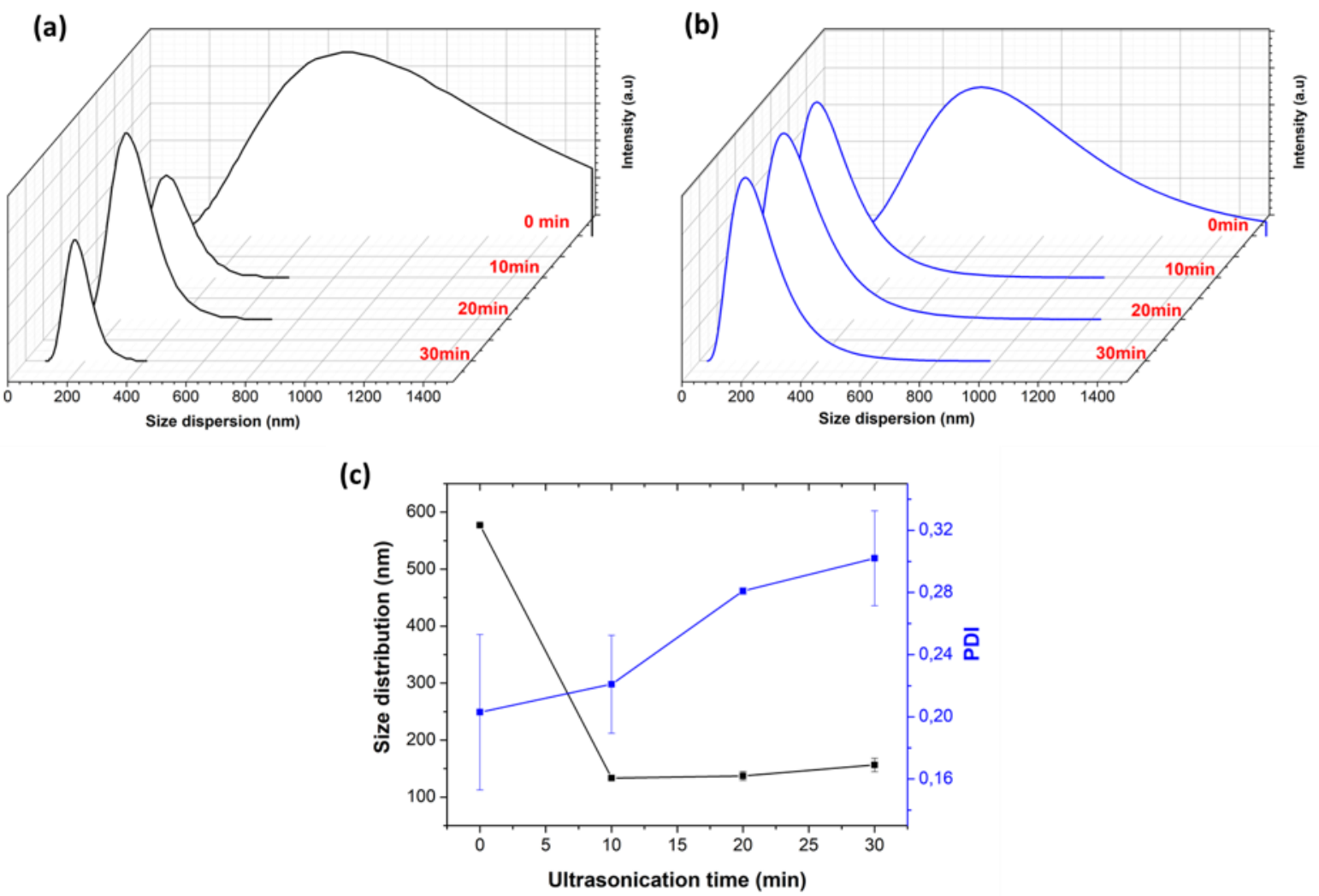

Fig 6 . 
n type (100) $\mathrm{Si} /$ pure $\mathrm{TiO}_{2} \quad$ n type (100) $\mathrm{Si} / \mathrm{TiO}_{2}: \mathrm{Er}-\mathrm{Yb}$
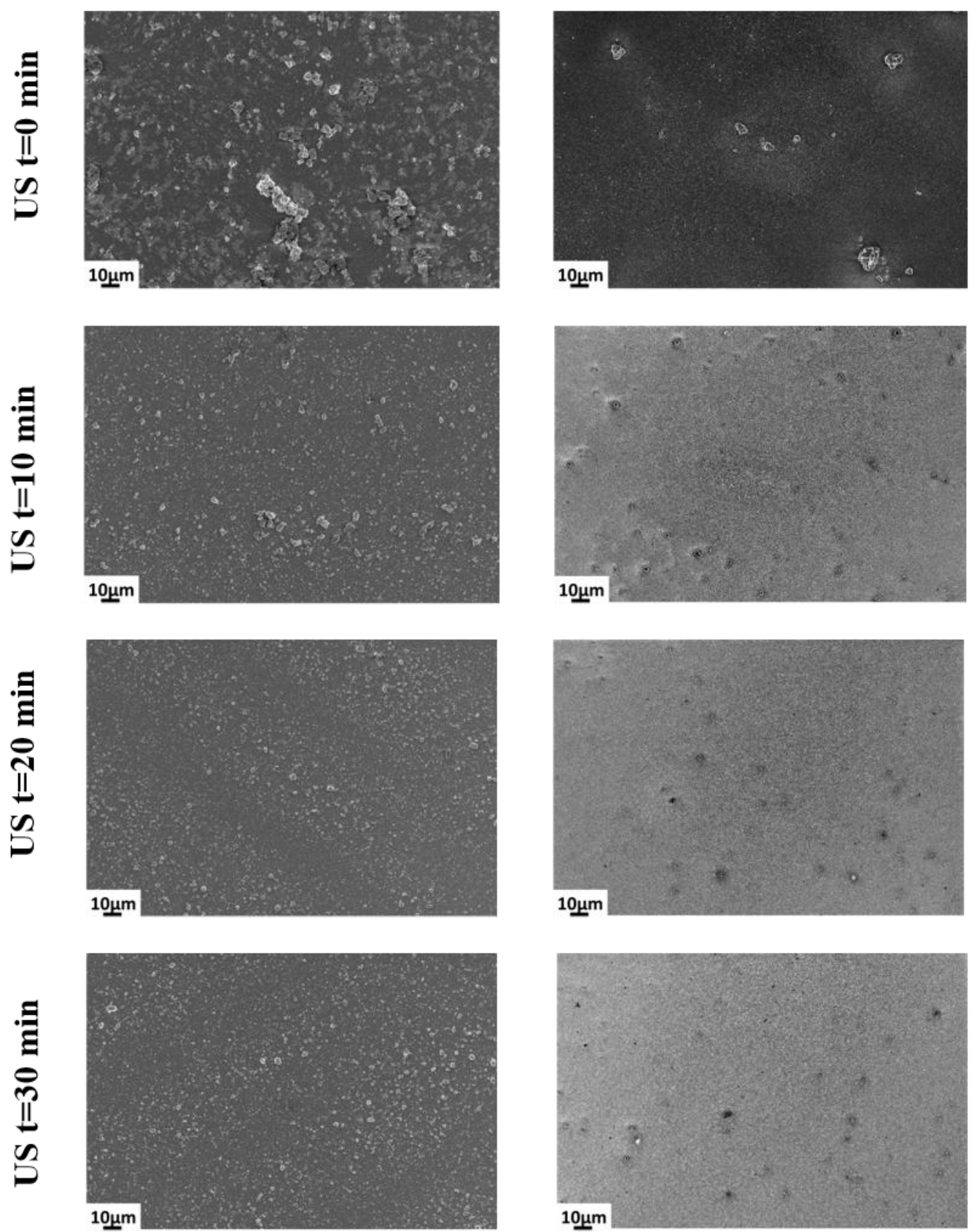

Fig 7. 

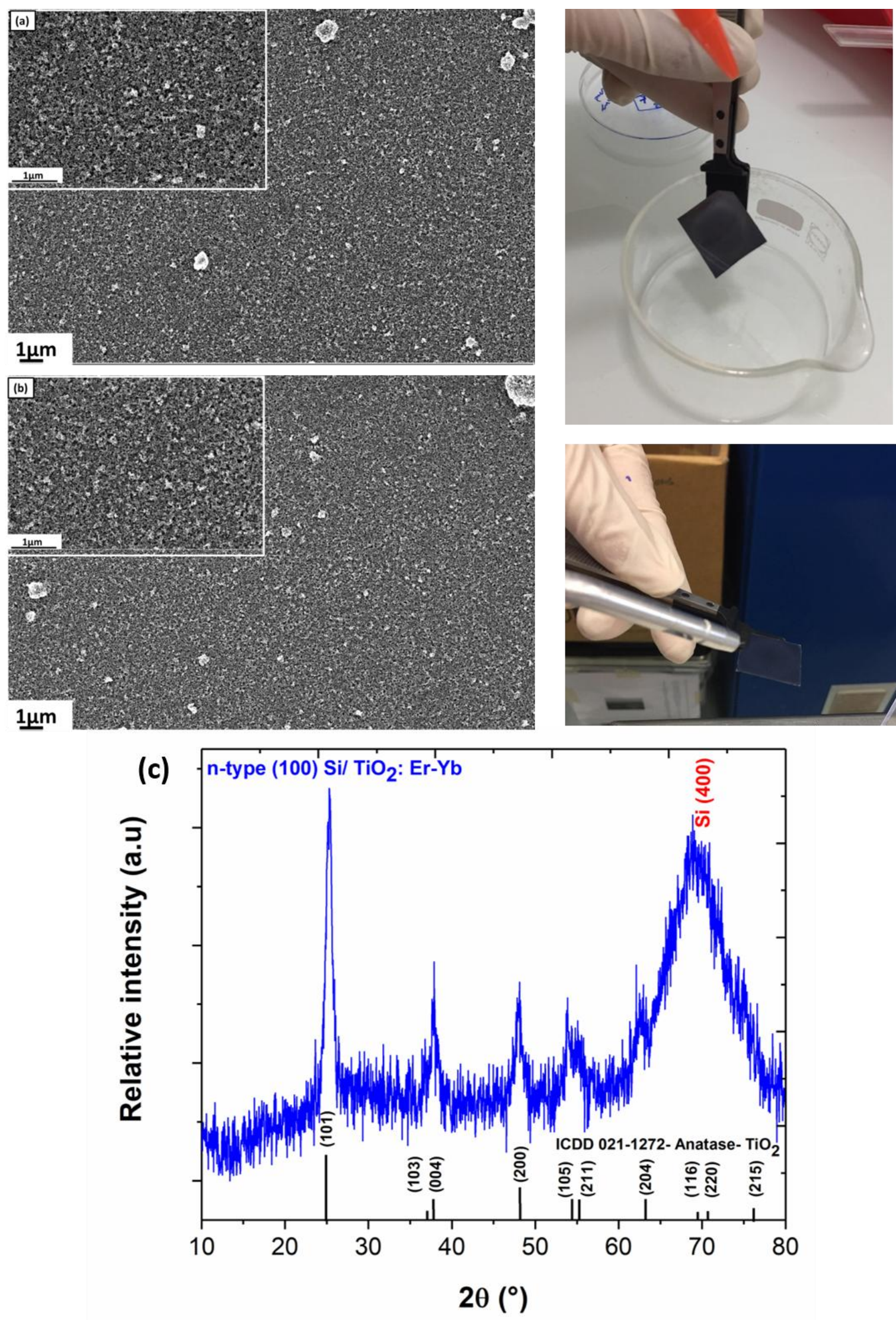

Fig 8 . 

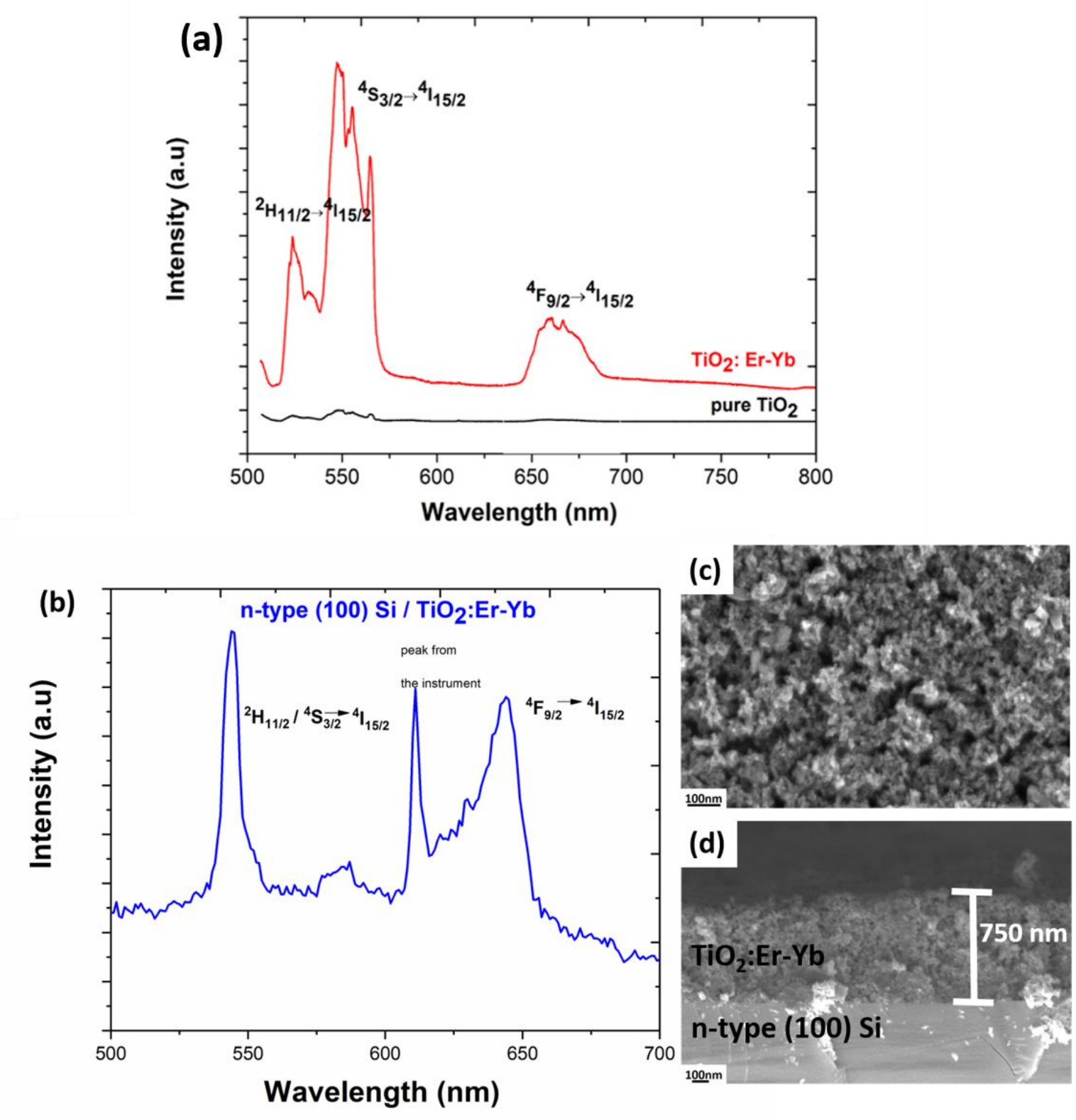

Fig 9. 


\section{List of tables}

Table 1. The crystallite size, lattice distortion and unit cell parameters obtained from XRD patterns.

Table 1.

\begin{tabular}{ccccccc}
\hline Sample & $\begin{array}{c}\text { Mean crystallite } \\
\text { size } \mathbf{D}(\mathbf{n m})\end{array}$ & $\begin{array}{c}\text { Lattice distortion } \\
\eta(\%)\end{array}$ & $\mathbf{a}(\AA)$ & $\mathbf{c}(\AA)$ & $\begin{array}{c}\text { c/a } \\
\text { ratio }\end{array}$ & $\begin{array}{c}\text { Unit cell volume } \\
\left(\AA^{3}\right)\end{array}$ \\
\hline $\mathrm{Pure}^{\mathbf{3}} \mathrm{TiO}_{2}$ & 9 & 0.07 & 3.7862 & 9.4970 & 2.5083 & 136.14 \\
\hline $\mathrm{TiO}_{2}: \mathrm{Er}-\mathrm{Yb}$ & 11 & 0.31 & 3.7923 & 9.5051 & 2.5064 & 136.69 \\
\hline
\end{tabular}

